\title{
Humor químico
}

Quem conheça o autor destas notas sabe bem que ele não é uma pessoa particularmente espirituosa. As frases humorísticas que se seguem e que têm sido usadas com êxito na sala de aula e circunstâncias afins, são, assim, a prova de que qualquer professor poderá criar (com um pouco de imaginação) e praticar humor químico nas suas aulas, recolhendo daí uma especial satisfação, e mais ainda, se ele fizer participar a criatividade, a imaginação e os conhecimentos químicos dos seus alunos na elaboração dos trechos humorísticos.

Um apreciável manancial resulta simplesmente do duplo sentido que certas palavras têm, designadamente na linguagem corrente e na linguagem química. Eis alguns exemplos:

1. Uma solução que não é concentrada... é distraída.

2. O produto duma reacção obtém-se ...multiplicando os factores de que ela depende.

3. O bom humor ou o azedume das pessoas depende... do pII do sangue.

4. Lei de Lavoisier ou da conservação da massa: "guarda o esparguete no frigorífico".

5. As soluções da equação de Schrödinger podem ser ... ácidas, básicas ou neutras.

6. Uma ligação covalente ... não é covarde.

7. Numa ligação amorosa há uma forte atracção física.

8. Energia radiante é... energia que se liberta em gargalhadas descontínuas.

9. A Mecânica Quântica é uma ciência tecnológica que necessita de muitas oficinas, "quantumaismelhor".

10. Molaridade: idade em que aparecem os dentes molares.

11. Os ácidos são menos que as bases pois além de bases de Brönsted-Lowry e bases de Lewis, há bases aéreas, bases de cones, bases de potências, bases dos partidos...

12. Lei da conservação de energia: não faças hoje o que podes deixar para amanhã $\left(1 .^{\circ}\right.$ Decreto-Lei da Termodinâmica).

13. Os metais são bons condutores... porque não bebem quando conduzem.

14. Constituição dum átomo: lei fundamental do mundo microfísico.

15. A precipitação não é... solução.

16. Uma conformação estrelada pode ser... mexida. *

17. O octano é menos volátil que o hexano... porque tem mais átomos de carbono na cadeia.

18. Grupo funcional: conjunto de pessoas que trabalha bem em grupo.

19. A dissolução dum parlamento é facilitada... em dias de chuva e de temperatura alta.
20. Os sais... nunca entram nos laboratórios.

21. As moléculas que sofrem reacção... têm dores agudas.

22. Picómetro: aparelho usado pelos alpinistas para medir a altura dos picos.

23. Energia, entropia, governar: funçð̃es de estado.

24. Os Electrōes de Valência... falam espanhol.

E agora alguns casos de tipo diferente embora jogando ainda com o sentido das palavras ou símbolos:

1. ATP: A Tabela Periodica.

2. Não R na aplicação da lei de S.

3. Nas soluçð̃es ácidas domina o ião H: três " 6 " mais!

4. A fenolftaleína cora em meio básico... porque é tímida.

5. O tornesol fica vermelho... de raiva quando the baixam o pII.

6. Termodinâmica: arte de trabalhar (W) para aquecer $(\mathrm{Q})$.

7. A estrutura atómica abohrrece-me! Schrodingo-me para os átomos na certeza de que alguém me heisenberga!

8. Boyle recebeu o prémio Nobel por ter inventado a água a ferver.

9. Diálogo entre químicos americanos:

- What is $\left(\mathrm{H}_{2} \mathrm{O}\right)_{4}$ ?

- Drinking! *

10. Diálogo entre químicos alentejanos:

- Ó homem aproveta!

- Qual proveta?

11. Diálogo entre físicos levianos:

- Como explicas a reacção $\mathrm{Hg} \rightarrow \mathrm{H}_{2}$ ?

- O g cai por acção da gravidade e o H liberta-se! *

O leitor estará por esta altura já convencido de como é fácil fazer humor químico. Envie as suas piadas para o editor do Boletim que certamente lhes dará a merecida divulgação.

* Exemplos adaptados de outros autores.

\footnotetext{
a Departamento de Química Universidade de Coimbra
} 